UDC 373.5(=162.4)(497.113 Bački Petrovac)

https://doi.org/10.18485/ms_zmss.2020.97.18

\author{
Zuzana Týrová \\ Univerzita v Novom Sade \\ Filozofická fakulta \\ zuzana.tyrova@gmail.com \\ Zuzana Týrová \\ University of Novi Sad \\ Faculty of Philosophy \\ zuzana.tyrova@gmail.com
}

\title{
STOROČNÉ PETROVSKÉ GYMNÁZIUM V PROCESE ZACHOVANIA SPISOVNEJ SLOVENČINY VO VOJVODINE A GRAMATIKY SLOVENČINY PRE STREDNÉ ŠKOLY A GYMNÁZIÁ1
}

\author{
ONE HUNDRED YEARS OF THE GRAMMAR SCHOOL \\ IN BAČKI PETROVAC IN THE PROCESS OF PRESERVING \\ LITERARY SLOVAK LANGUAGE IN VOJVODINA \\ AND THE GRAMMAR OF SLOVAK LANGUAGE \\ FOR HIGH SCHOOLS AND GRAMMAR SCHOOLS
}

Vyučovanie a pestovanie slovenského spisovného jazyka (ako jedného zo základných činitelov zachovania identity) na gymnáziu v Petrovci bolo jedným z primárnych ciel'ov od samotného zakladanie tejto významnej ustanovizne dolnozemských Slovákov. Učebnice boli dlho problém, lebo sa obstarávali najprv zo Slovenska. Učitelia museli byt' vynaliezaví aby žiakom umožnili kvalitné vedomosti a dobré podmienky na učenie sa. Prvú gramatiku slovenčiny pre 1. a 2. ročník vydal akademik Ján Kmet’ v roku 1952, d’alši pre 3. a 4. vydal v roku 1954. Potom sa ako odborníčka a autorka stredoškolských učebníc zjavila naša význmná lingvistka Mária Myjavcová, ktorá vydala v roku 1976 prvú učebnicu, d’alej v roku 1988 d’alšie a v 21. storočí vyšiel komplet pre stredné školy pozostávajúc z troch učební $(2005,2006,2009)$

Klúčové slová: Gymnázium Jána Kollára, Ján Kmet', Mária Myjavcová, slovenčina, srbčina, gramatiky/učebnice pre gymnáziá a stredné školy.

The teaching and cultivation of the Slovak literary language (as one of the basic factors of identity preservation) at the Grammar School in Petrovec was one of the pri-

1 Príspevok je individuálny čiastkový výsledok v rámci projektu Diskurzy menšinových jazykov, literatúr a kultúr v juhovýchodnej a strednej Európe (č. projektu 178017, vedúca projektu: prof. Dr. Anna Makišová), ktorý financuje Ministerstvo osvety, vedy a technologického rozvoja Republiky Srbsko. 
mary goals since the very founding of this important institution of the Slovaks from Vojvodina. Textbooks have been a problem for a long time. First the ones from Slovakia were used. Teachers had to be resourceful to provide students with good knowledge and good learning conditions. The first grammar of Slovak (first and second years) was written by the academic Ján Kmet' in 1952, the second was published in 1954 (for the third and fourth year). Then our distinguished linguist, Mária Myjavcová, appeared in 1976 as an expert and author of secondary school textbooks, second textbook was published in 1988 and in the 21st century a complete set for secondary schools consisting of three textbooks was published $(2005,2006,2009)$

Keywords: Ján Kollár Grammar School, Ján Kmet', Mária Myjavcová, Slovak, Serbian, grammar / textbooks for grammar schools and secondary schools.

\section{Úvodné poznámky}

Školstvo je bezpochyby jednou z najzávažnejších oblastí v l'udskom živote. Človek by sa mal vzdelávat' v jazyku, ktorý mu je najbližší, a to je materinský jazyk, lebo tak najlepšie chápe veci a pojmy. Slováci vo Vojvodine si vd’aka vzdelávaniu v materčine vo vel'kej miere zachovali národnú identitu. Žiaci sa na školách učia spisovný slovenský jazyk, čo je pre tunajšie prostredie vel'mi dôležité, lebo sa doma a na ulici prevažne rozprávajú nárečím. Ked’ ide o školenie v materinskom jazyku, význam tejto kultúrnej činnosti znásobuje sa v oblastiach osídlených rôznymi etnickými skupinami. Okrem základného účelu, vzdelávanie a výchovy, školenie v materinskom jazyku má osobitnú, vel'mi dôležitú úlohu, a to je boj o zachovanie etnickej identity, o zachovanie jazyka jednej menšiny a uvedomenie si svjbytnosti.

Vo Vojvodine má slovenské školstvo bohatú tradíciu, lebo si Slováci po príchode na Dolnú zem, okrem vlastných príbytkov stavali aj školské budovy a zakladali cirkev. Klúčcovým faktorom pri zachovaní slovenskej národnej identity až po súčasnost' bola prítomnost' inteligencie (kňazi a učitelia) v slovenských obciach vo Vojvodine takmer od začiatku pristahovania. O tomto Andrej Mráz hovorí: „Do ktorých slovenských krajov na Dolnej zemi najsystematickejšie cez desatročia prichádzali učení l'udia zo starej vlasti, tie kraje ostali národne najzachovalejšie a najaktívnejšie... Nebyt tých desiatok vzdelaneckých rodin od konca 18. storočia do prvej svetovej vojny medzi vojvodinskými Slovákmi, pravdepodobne by totiž len bledá pamiatka na slovenských predkov ostala.“ (Mráz 2004: 57).

Prvé školy boli zakladané pri cirkvi a vel'mi často učitel'mi boli samotní evanjelickí farári. Ale, v niektorých osadách si učitel’a volili aj pred farárom, najmä pred vydaním Tolerančného patentu Jozefa II. z roku 1781 (kým ešte evanjelické osady ani nemohli mat' svojho farára). Napríklad Petrovčania, Selenčania a Hložančania mali skôr učitel'a, ako farára, a pre nedostatočný počet farárov si potom hned' po schválení patentu povyšovali bývalých učitel'ov na kňazskú hodnost' (Pivničania, Selenčania a Lalitania). Okrem iných funkcií v školskom, cirkevnom a obecnom živote mal učitel' dôležitú úlohu: prenášat' znalost' písma na deti. Postupne slovenské osady vo Vojvodine hospodársky 
silneli, počet obyvatel'ov sa zvyšoval, a preto si pozývali viac učitel’ov, resp. kaplánov do väčších evanjelických zborov, a to neraz aj zo Slovenska. Vývin škôl takmer vo všetkých slovenských osadách na území Vojvodiny mal vela spoločných alebo podobných čŕt. Siet' slovenských menšinových škôl bola ku koncu 19. storočia dobre vybudovaná. Andrej Mráz však konštatuje, že pred 1. svetovou vojnou sedliaci nedôverovali príliš ,učenosti“, a preto svoje deti nechceli dávat’ do škôl (Mráz 2004).

Situácia sa zmenila hlavne po roku 1918, po skončení prvej svetovej vojny, ked' sa Slováci z južných oblastí ocitajú v novom štátnom zriadení. Rozpadom Rakúsko-Uhorska a vznikom Královstva Srbov, Chorvátov a Slovincov, neskôr Královstva juhoslovanského, sa dostávajú do novej zlomovej pozície, ked' boli odlúčení od svojho materského štátu. Práve toto vplývalo na zvýšenie kultúrnych, spoločenských, hospodárskych a politických aktivít. Výsledkom bolo budovanie inštitucionálnych základov slovenskej menšiny. Už roku 1919 v Petrovci bola založená tlačiareň Kultúra, v ktorej sa tlačia slovenské učebnice a knihy. V tom istom roku sa prvýkrát uskutočňujú Slovenské národné slávnosti, na ktorých Slováci prezentujú svoju kultúru. Zakladajú sa d’alšie spolky a divadelné skupiny. Bol to zároveň aj prelomný bod v školstve vo Vojvodine, ked' bolo otvorené slovenské gymnázium v Petrovci (v roku 1919/1920) najprv ako dvojtriedne: Založenie gymnázia priaznivo vplývalo na kultúru a táto inštitúcia sa stala jedným zo základných pilierov zachovania slovenského jazyka a národnej identity. Týmto vyvrcholilo vysoké národné povedomie a vyspelost' Slovákov žijúcich v južnej časti Rakúsko-Uhorska začiatkom 20. storočia.

Ešte v polovici 19. storočia Ján Kollár vyslovil myšlienku, že treba založit’ nejakú strednú školu, kde sa budú učit' Slováci z Báčky, Banátu a Sriemu. Ubehlo však ešte dost' času, kým sa táto myšlienka realizovala. Slovenské reálne nižšie gymnázium v Petrovci svoje brány otvorilo 1. októbra 1919. Vtedy petrovský evanjelický kňaz Samuel Štarke, ako predseda jeho kuratória, slávnostne uviedol do úradu prvých prednášatel'ov. Gymnázium najprv pracovalo v ,„státnej škole“ a v súkromnom dome Pavla Boldockého, ktorý na dva školské roky 1921/22 a 1922/23, pre gymnázium bezplatne poskytol dve učebné siene, jednu miestnost' pre zborovňu a byt pre školského sluhu. Od roku 1923 má gymnázium vlastnú budovu, postavili ju vojvodinskí Slováci z vlastných dobrovol'ných príspevkov, za finančnej pomoci vlády ČSR a Slovákov zo zámoria, v značnej miere vlastnou dobrovol'nou prácou.

Prvé obdobie pôsobenia gymnázia (1919-1924) bolo v znamení konštituovania gymnaziálneho života, riadneho profesorského zboru a výstavby osobitnej budovy gymnázia, ked’že začiatkom mája 1922 prišlo z Belehradu oznámenie, že ak do začiatku budúceho školského roku gymnázium nebude mat' vystavanú svoju budovu, bude zatvorené, a že Belehrad nemieni ničím prispiet' k stavbe budovy. K zániku gymnázia, predsa nedošlo, lebo budova bola v r. 1923 postavená.

Petrovské gymnázium je najvýznamnejšou stredoškolskou inštitúciou, ktorá nepretržite pracuje od roku 1919 a je najstarším slovenským gymnáziom 
mimo hraníc Slovenskej republiky. Celkový počet maturantov absolventov petrovského gymnázia končiac školským rokom 2018/19 je 4668. Väčšina slovenských vojvodinských intelektuálov, kultúrnych dejatelov, úspešných osobností vo všetkých sférach sú odchovancami tohto gymnázia. V rámci neho pôsobila učitel'ská škola (ako stredná škola) v rokoch 1947-1966, s 216 absolventmi, ktorí takisto prispeli k zachovaniu národnej identity tunajších Slovákov. V rokoch 1975-1990 gymnáziá boli zrušené a od školského roku 1990/91 ich znovu uviedli. K zvýšeniu počtu žiakov Slovákov na petrovskom gymnáziu prispel aj novovybudovaný žiacky domov. Tak napríklad Slováci zo Sriemu, ktorí dovtedy obyčajne pokračovali v školení v srbčine, prichádzajú do Petrovca, hoci mali napríklad od 5. po 8. ročník výuku v srbčine (ako napr. žiaci z Erdevíka). Kompletná výuka sa tu koná v slovenčine a každoročne bývajú po dve slovenské triedy, resp. tri a jedna, alebo dve srbské.

Ako sme už spomenuli, v priebehu svojej storočnej existencie gymnázium prežilo viacero štátnych útvarov a tým aj zmenu názvu. Štátne slovenské reálne gymnázium, ako bolo nazvané pri jeho vzniku prežilo nepriaznivé vojnové roky, ale aj napriek tomu sa v polovici 20 . storočia podarilo gymnáziu zotrvat', dokonca zvýšit' počet žiakov a tried, a vzhl'adom na situáciu boli otvorené aj triedy so srbským vyučovacím jazykom. Triedy v porovnaní so začiatkom postupne pribúdali, a tak napr. v roku 1946/47 bolo zapísaných 700 žiakov. Na začiatku tam vyučovalo vel'a neslovenských učitel’ov, ale sa situácia postupne menila. V d’alšom dost' turbulentnom období v sústave juhoslovanského školstva prebiehali systémové zmeny. Vtedy boli školy transformované na vzdelávacie strediská, čomu sa nevyhlo ani petrovské gymnázium. V roku 1990 gymnázium znovu nadobudlo charakter inštitúcie štvorročného všeobecno-vzdelávacieho stredoškolského zamerania. Počas osláv 50. výročia škola dostala i nové meno Gymnázium Jána Kollára v Petrovci, podla slovenského básnika, zberatel'a l'udovej slovesnosti, estéta a zástancu slovanskej vzájomnosti, ktorý už r. 1849 navrhoval založit’ v Petrovci slovenské gymnázium a vtedy bolo zorganizované aj vedecké sympózium (5. a 6. október 1969), za aktívnej účasti vel'kého počtu popredných kultúrnych a vedeckých pracovníkov a spisovatel’ov z Juhoslávie a Slovenska. Ako výsledok tohto sympózia je zaujímavá publikácia pod názvom Petrovské gymnázium vo vývine slovenskej kultúry vo Vojvodine a Pamätnica I.

Vo svojich, dnes už storočných dejinách, gymnázium často zápasilo s radom problémov, avšak vždy dokázalo preklenút' ich a nie iba pokračovat' vo svojom pôsobení, a všestranne zvel'ad'ovat' svoju činnost'. Už v čase svojho vzniku bolo svojráznym fenoménom najmä preto, lebo vzniklo v dedinskom prostredí, $\mathrm{v}$ radoch relatívne málopočetnej národnostnej enklávy na podklade vlastných síl a hmotných prostriedkov a dlhé roky bolo jediným gymnáziom zo slovenským vyučovacím jazykom (vo všetkých predmetoch) mimo Slovenska. Zotrvalo preto, lebo sa vždy prispôsobovalo dobe a reformám vo výchovnovzdelávacom procese na úrovni štátu. V situáci, ked’ sa počet žiakov znižuje, nie len na mnšinových školách, ale všade, prispelo i vybudovanie moderného 
žiackeho domova v školskom roku 1998/99, vybudovaný za finančnej pomoci vlád Slovenskej republiky a Srbskej republiky. Jeho kapacita (75 lôžok) občas nestačí pre potreby a záujem žiakov, ktorí by chceli navštevovat' túto školu, a preto musia vynaložit' úsilie, aby mali to privilégium a bývat' tu.

Počas storočia gymnázium viedlo 24 riaditel’ov, ktorí určite pozitívne prispeli na pôsobenie gymnázia. Boli to: Július Kubány (prvý dočasný riaditel'), Jozef Šimek, Ludevít Slaný, Vuk Puljević, Nikola Polovina, Pavle Tvrtković, Dimitrije Đurović, Miloje Stojadinović Jovan Ristić, Božidar Širola, Đorđe Mrkobrad, Dragutin Galijan, Stanko Dragosavljević, Michal Rapoš, Dr. Andrej Sirácky (neskôr akademik ČSR), Pavel Cesnak, Michal Cinkotský, Ivan Križan, Branislav Spevák, Pavel Mučaji, Samuel Spevák, Viera Boldocká, Palo Belička a Anna Medved’ová.

Okrem petrovského gymnázia, ktoré dlhé roky bolo jedinou stredoškolskou ustanovizňou v bývalej Juhoslávii na vzdelávanie slovenskej menšiny, netreba zabudnút' a spomenút' aj Gymnázium Mihajla Pupina v Kovačici, kde sa od roku 1975 vyučuje aj po slovensky. V každom ročníku tu mávajú aj po jednu slovenskú triedu. Dovtedy banátski Slováci tiež navštevovali gymnázium v Petrovci, ale po tomto roku, situácia sa mení.

V novšej dobe a po rôznych reformách školstva, Slováci si často volia stredné odborné školy. Pomerne vel'ký počet dievčat navštevuje napr. strednú zdravotnícku školu a preto tu existovali reálne možnosti, aby od školského roku 2013/2014 bola otvorená jedna slovenská trieda.

\section{Petrovské gymnázium a zvel'ad’ovanie spisovnej slovenčiny}

Na zachovanie slušnej úrovne spisovnej slovenčiny je potrebné pestovat' jazykovú kultúru na všetkých úrovniach. Vel'kú úlohu v tom majú základné a stredné školy s vyučovacím jazykom slovenským. Nemyslitel'ný je d’alší úspešný rast bez dobrej jazykovej úrovne v školách. Používatelia slovenského jazyka by mali ovládat' slovenskú terminológiu svojho odboru a štýl ich spisovnej slovenčiny by mal byt' primeraný ich odboru a činnosti. Predovšetkým hovoríme o učitel'och a profesoroch, čo vyučujú po slovensky, ale i l'udí z iných úsekov. Úloha petrovského gymnázia $v$ tom bola, a mala by byt' aj nad’alej ústredná. Preto o význame petrovského gymnázia v zachovaní a zvel’ad’ovaní slovenčiny naznačujú tieto slová profesora Daniela Dudka: „Boj o slovenské gymnázium je aj bojom o prenikanie a upevňovanie spisovnej slovenčiny v našom prostredi.“" (1970: 298).

Petrovské gymnázium vo vel'kej miere vplývalo na kultivovanie spisovnej slovenčiny vo Vojvodine, a viedlo žiakov k tomu, aby si vážili a uctievali svoj materinský jazyk. Pre školu boli príznačné aj mimotriedne a mimoškolké aktivity prispôsobené kultúrnym a iným potrebám prostredia. Tieto aktivity mali východiská v Žiackom samovzdelávajúcom krúžku Sládkovič, založenom už v r. 1925. Z neho vyrástli mnohí slovenskí kultúrni dejatelia, takmer všetci 
významní spisovatelia slovenskej menšiny a tento krúžok je ešte stále aktuálny a prispieva, aby sa slovenský jazyk neučil iba na hodinách jazyka. Pri príležitosti pät'desiatročnice jeho založenia bolo usporiadené vedecké sympózium, z ktorého následne vyšla kniha Samovzdelávajúci (1976).

Význam gymnázia $\mathrm{v}$ zachovaní slovenčiny si uvedomovali nielen jeho odchovanci, ale i vedeckí pracovníci zo Slovenska. Ako sme už povedali, vzdelávanie v materinskom jazyku je vel'mi dôležité, a často sme si toho ani nie vedomí, až ked' sa stane, že toto naše právo môže byt' v ohrození. Jazyk sa vyučujuje tak na hodinách jazyka, ako i na ostatných predmetoch. Poznanie vlastnej kultúry, ale i kultúry vôkol nás rozširuje obzory. O tomto hovorí aj Jozef Stolc: „V slovenskej škole vystupuje do popredia predovšetkým to, že popri učebných predmetoch podávaných $v$ slovenskom jazyku je osobitným predmetom aj sám slovenský jazyk. A práve toto treba pri petrovskom gymnáziu aj osobitne zdôraznit'. Lebo to udržiavalo a rozširovalo duchovné obzory Slovákov v Juhoslávii. Jazykové vzdelanie a systematická jazyková výchova zvyšovala konzum slovenského slova v jeho literárnej podobe a na druhej strane formovala tvorcov literárnych diel, krásnej a odbornej literatúry, publicistiky atd”. To je zásluha petrovského gymnázia." (1970: 293).

Podobne zmýšla aj Mária Myjavcová, vojvodinská lingvistka, ktorá sa celý život venovala praktickému použivaniu slovenčiny u nás, vydala celý rad praktických príručiek, kvalitných učebníc a stále bojovala o uvedomenie si podstaty spisovnej slovenčiny, ktorá je $\mathrm{v}$ takomto mnohojazykovom $\mathrm{v}$ prostredí v určito ohrozená a zdôraznila: „Celkove platí konštatácia, že spisovný slovenský jazyk má v takomto heterogénnom jazykovom spoločenstve, akým je naše enklávne a pritom územne nekompaktné spoločenstvo, silnú integrujúcu úlohu. Túto úlohu spisovná slovenčina splínala uż v minulosti, a to nielen vd'aka slovenským školám, ale aj vd'aka relativne rozvinutému kultúrnemu životu. Slovenskú inteligencia v minulosti bola sice ešte menej početná, ale zato zanietená za slovenskú vec, rozvíjala organizovanú l’udovychovnú a kultúrno-osvetovú činnost', kam patrilo aj slovenské tlačené slovo, slovenské divadelnictvo, l'udovychovné prednášky a publikácie, potom kultúrne aktivity Matice slovenskej v Juhoslávii spolu s jej časopisom Náš život a pod. To všetko boli medziiným aj príležitosti na použivanie spisovnej podoby slovenského jazyka, s čím sa priamo spájalo aj pestovanie jazyka." (Myjavcová 2009: 139)

Gymnázium počas svojho pôsobenia malo významnú úlohu v upevňovaní spisovnej slovenčiny. Odchovanci gymnázia sa snažili používat', zvel'ad’ovat' a vážit' si slovenský spisovný jazyk. Práve oni boli jazykovým vzorom, vyikajúcimi odborníkmi nielen v oblasti spoločenských vied, ale aj prírodných. Učebnice z iných predmetov prekladali profesori tohto gymnázia a snažili sa aj v neprajných rokoch ked' situácia medzi Československom a Juhosláviou nebola prajná, zabezpečit' si knihy, poznat' súčasnú terminológiu zo všetkých oblastí. Žial', ked' situácia nebola prajná, jazyková úroveň bola omnoho lepšia, a teraz, ked' je prístup $\mathrm{k}$ informáciám ovel’a l'ahší, naši učitelia často nie sú jazykovým vzorom pre svojich žiakov a nesnažia sa použivat' spisovný jazyk, 
ale v bežnej komunikácii používajú aj nárečie. Skôr to bolo inak: „S rozvojom a trvaním gymnázia, ako jedinej strednej školy tunajších Slovákov, na ktorej sa vyučovalo po slovensky, stále širšie prenikala a upevňovala sa v tomto prostredi aj spisovná slovenčina. Bol to velmi významný prvok v kultúrnom živote tunajšich Slovákov i základný predpoklad pre ich d'alši rast. (Dudok 1970: 298)

\section{Učebnice/gramatiky slovenského jazyka pre stredné školy/gymnáziá vo Vojvodine}

Jednou z dôležitých podmienok na kvalitné vyučovanie $\mathrm{v}$ materinskom jazyku vo viacjazykovom prostredí akým je Vojvodina, v nemalej miere prispievajú aj dobré učebnice. $V$ dnešnej dobre sa učebnice pre gymnázia, podobne ako aj učebnice pre základné školy prekladajú. Jedinou výnimkou sú čítanky a gramatiky zo slovenského jazyka. V minulosti bola situácia omnoho horšia, lebo napriek tomu, že sa vyučovanie konalo v slovenčine, žiaci sa učili zo srbských učebníc a odpovedali po slovensky. O tom, aké sa učebnice používali sa dozvedáme z jednotlivých Pamätníc. V medzivojnovom období sa používali učebnice zo Československa, a tak aj učebnice slovenského jazyka a slovenskej literatúry. Až v 50-tych rokoch vznikla prvá učebnica slovenského jazyka. Je paradoxné, že k tomu prispela neprajná situácia medzi Československom a bývalou Juhosláviou. Nemohli sa používat' učebnice z vtedajšieho Československa, preto sa učivo prekladalo zo srbských učebníc, alebo sa látka zo všetkých predmetov diktovala. Učebnicová literatúra má preto u nás dávnu tradíciu. Učebnice slovenčiny pre všetky stupne škôl (najnovšie aj pre slovenské škôlky) zostavovali a zostavujú naši domáci autori, a to vždy so zretel'om na základný opis spisovnej slovenčiny. Dlhý čas po druhej svetovej vojne sa naše učebnice, ako aj učebnice všetkych jazykov vo Vojvodine, tlačili vo vojvodinskom vydavatel'stve učebníc, kde pôsobí aj slovenská redakcia. Toho času v novosadskom vydavatel'stve prebieha príprava učebníc a samo vydávanie učebníc obstaráva učebnicové vydavatel'stvo Srbska v Belehrade.

Vydanie prvej učebnice slovenčiny siaha po roky po duhej svetovej vojne. Mladý pedagogický pracovník, neskôr jediný akademik z radov vojvodinských Slovákov, Ján Kmet’ v roku 1952 napísal Slovenskú gramatiku pre I. a II. triedu slovenských stredných škôl vo FL'RJ, ktorá bola prvou učebnicou slovenského jazyka pre stredné školy. V úvode autor hovorí: Z tejto knihy budete sa učit' porozumiet' všetko, čo kdekol'vek budete čitat', bezchybne rozprávat'všetko, čo budete chciet' povedat' a správne pisat' všetko, čo budete chciet' napísat' (Kmet' 1952: 5). O skutočnosti, že spisovný jazyk bol v tom období vel'mi dôležitý, že sa budúci intelektuáli, žiaci stredoškoláci snažili dobre zvládnut' spisovný jauyk svedčí aj d’alšia poznámka v úvode: Gramatika sa nedá učit z knihy, ale len zo živého jazyka, ktorým hovoríme a ktorým sa v knihách pišse. Preto pri každom gramatickom a pravopisnom pravidle, všimajte si a analy- 
zujte nielen tie vety, ktoré sú v gramatike, ale aj mnohé iné vety z čitanky, z knihy alebo z novín. (Kmet' 1952:5). Táto gramatika bola útlučká a mala iba 152 strán.

O dva roky neskôr, čiže v roku 1954 vydáva Ján Kmet' Slovenskú gramatiku pre III. a IV. triedu gymnázia alebo VII. a VIII. triedu osemročných škôl, ktorá už mala 229 strán. Týmto sa tieto dve učebnice stali základnou pomôckou na hodinách slovenčiny. Bol to prehl'ad celkovej slovenskej gramatiky a dobrá pomôcka a hodinách jazyka. Neskôr sa Kmet’ venoval výlučne slovenskej literatúre a príprave čítaniek.

Ďalším dôležitým obdobím bol rok 1976 kedy sa ako zostavovatel'ka učebníc, čiže gramatík pre stredné školy objavila Dr. Mária Myjavcová. Ona sa medzi vojvodinskými Slovákmi osvedčila ako dobrá pragmatička, ale aj autorka učebníc slovenského jazyka. O učebniciach pre základné a stredné školy sa zmienila aj Anna Makišová (2014). Na rozhraní šest'desiatych a sedemdesiatych rokov s Františkou Častvenovou zostavila štyri učebnice a štyri cvičebnice slovenského jazyka pre 5., 6., 7. a 8. ročník základnej školy. Roku 1976 vypracovala svoju prvú stredoškolskú gramatiku (pre dva ročníky), pod názvom Slovenský jazyk pre 1. a 2. ročník strednej školy, ktorú vydal novosadský Pokrajinský ústav pre vydávanie učebníc, a mala 183 strán. Ďalšie vydania tejto učebnice vyšli pod názvom Slovenský jazyk pre 1. a 2. ročník spoločnej stredoškolskej výchovy a vzdelávania v rokoch 1978 (2. vydanie), 1981 (3. vydanie) a posledné štvrté v roku (1985). Musíme pripomenút', že v tomto období bol povinný deviaty a desiaty ročník základnej školy, a spoločné stredoškolské vzdelanie bolo iba dvojročné. Mária Myjavcová vždy stála na stanovisku bytostnej zviazanosti spisovnej slovenčiny používanej vo vojvodinskom prostredí so slovenským jazykom v jeho materskom prostredí na Slovensku. Aj v učebniciach sa zaujímala o osud slovenského jazyka a najmä spisovnej slovenčiny vo vojvodinskom prostredí, ktoré sa výrazne menilo, a vplývalo aj na samotný jazyk. Neraz sa zamyslela aj nad tvorbou a kvalitou učebníc v našom prostredí a tak poznamenala: „V našom prostredí, ked’že sme aj $v$ minulosti mali naše slovenské školstvo (aspoň v monolitnejšich slovenských prostrediach) bola vždy zjavná snaha čo najstriktnejšie dodržiavat' spisovné normy slovenského jazyka. Táto zásada sa uplatňovala už pri vyučovaní slovenčiny, ale aj ostatných predmetov a práve tak sa brala do úvahy aj pri tvorbe učebníc slovenského jazyka a čítaniek, tiež pri vydávaní prekladov srbských učebnic, ako aj pri vydávani našich pôvodných slovenských alebo do slovenčiny prekladaných srbských literárnych a iných textov. Tieto snahy boli viac či menej podlamované istými nepriaznivými okolnostami. Tak voblasti vyučovania slovenčiny to bola striktná a dlhú dobu platná požiadavka prihliadat pri tvorbe našich učebných osnov a pri metódach spracovania učebnicovej literatúry na tie učebné rámce, ktoré sú formulované pre materinsky srbskýjazyk. “ (Myjavcová 2009: 149)

Po zmenách v oblasti vzdelávania, ked’ bol vrátený starý stredoškolský švorročný systém, profesorka Myjavcová v 90. rokoch pripravila d'alšiu učeb- 
nicu Slovenský jazyk a kultúra vyjadrovania pre 1.-4. ročník strednej školy, ktorú ocenili ako dobrú a jedinečnú príručku mimo územia Slovenska aj poprední slovenskí lingvisti, pracovníci Jazykovedného ústavu L'udovíta Ștúra Slovenskej akadémie vied v Bratislave. Tak napr. Ján Kačala poznamenal: „Slovenský jazyk a kultúra vyjadrovania od M. Myjavcovej je učebný text napísaný s prehl'adom skúseného vedeckého pracovnika a popularizátora poznatkov o slovenčine. Zo slovakistického hl'adiska sú pozoruhodné najmä zistenia o situácii slovenčiny v cudzojazyčnom prostredi Vojvodinskej oblasti Juhoslávie a o dosahu tohto činitela na tamojšiu podobu slovenčiny. Možno vyslovit' presvedčenie, že táto učebnica poprednej vojvodinskej slovakistky $M$. Myjavcovej bude dobre plnit úlohy, na ktoré je určená." (Kačala 182-183).

Táto učebnica mala až 5 vydaní $(1988,1990,1994,1998$ a 2000) a bola to jednotná učebnica pre všetky štyri ročníky gymnázia, resp. strednej školy. Bola praktická a didaktická pomôcka pre slovenčinárov a z formálnej stránky bola dobre koncipovaná. $\mathrm{V}$ porovnaní s predchádzajúcou učebnicou, $\mathrm{v}$ tejto boli obsiahnuté všetky roviny jazyka a bolo tu aj učivo z oblasti kontaktu slovenčiny a srbčiny, akými sú napr. kalkovanie, zmeny v používaní slov, preberanie slov zo srbčiny. Oproti učebniciam zo Slovenska, bola tu kapitola O jazyku, kde si autorka všímala jazyk vo vtedajšej Juhoslávii, tak nárečovú podobu ako aj spisovný jazyk a jeho špecifiká v rámci kontextu vojvodinských Slovákov. Táto učebnica bola skôr pomôcka pre učitel'ov a žiakov, ktorí si chceli precvičit' znalosti z jazyka, lebo koncepcia úloh nebola na vel'mi vysokej didaktickej úrovni, a priestor na precvičovanie úloh nebol dobre využitý. V učebnici sa kládol vel'ký dôraz na jazykovo-kontaktné vzt’ahy slovenčiny a srbčiny. Po definíciách, podkapitolách sa často obracala na žiakov s upozorneniami, čo je náležité a čo nenáležité $\mathrm{v}$ spisovnej slovenčine. $V$ prvých štyroch vydaniach bolo vyznačené, ktoré učivo je, pre ktorý ročník, kým v poslednom, piatom vydaný takého vyznačenie už nebolo. Treba napomenút', že aj napriek tomu, že by sa jazyk a garamatika mali vyučovat' v stredných školách, predsa sa viac pozornosti venuje literatúre a učivu z jazyka sa pozornost' venuje iba okrajovo. Preto môžeme povedat', že sa učebnice z jazyka, čiže gramatiky, prevažne používajú pri prípravu žiakov na sútaže zo slovenského jazyka.

Ďalšie obdobie tvoria roky v 21. storočí. Mária Myjavcová, ktorá sa nezištne venovala slovakistike cez celý svoj pracovný vek s tvorbou neprestala ani na dôchodku a opät' prejavila a do tretice zostavila tri učebnice (Myjavcová $2005,2006,2009)$, v ktorých sa vo vel'kej miere venovala aj slovenskosrbskému bilingvizmu a vplyvu srbčiny na slovenčinu. K vyučovaniu jazyka sa stavala zodpovedne a postrehy z praxe a výskumný materiál podala zaujímavo. Predmetom jej skúmania a praktických poznámok, bola celková situácia v používaní slovenčiny vo Vojvodine, teda vo všetkých funkčných štýloch.

Belehradský Ústav pre učebnice a učebné pomôcky - vlastne jeho vysunuté oddelenie v Novom Sade - správne konali, ked' požiadali Dr. Máriu Myjavcovú vypracovat' novú učebnicu, v ktorej by sa brali do úvahy najnovšie osnovy vypracované v rámci Asociácie slovenských pedagógov a schválené 
príslušnými školskými orgánmi. Pôvodne to mala byt’ iba jedna kniha pre všetky štyri ročníky, ale autorka pripravila taký obsiahli rukopis, ktorý pozostával z troch celkov (prvá čast' sa mala prebrat' v 1. ročníku, druhá čast' v druhom ročníku a tretia čast' $v$ 3. a 4. ročníku, pričom v záverečnom ročníku by sa stredoškolské učivo zo slovenského jazyka aj systematizovalo), a recenzenti navrhli, aby vyšli až tri knihy, čo sa nakoniec aj stalo. O vzniku týchto učebníc autorka poznamenala: „Roku 2002 sme u nás vypracúvali nové učebné osnovy pre základnú a strednú školu a pritom sme už zohladñovali aj našu celkovú jazykovú situáciu. Podl'a novej koncepcie boli potom už vypracované nové učebnice slovenčiny pre všetky ročníky gymnázia. V týchto učebniciach sa žiaci oboznamujú s hlavnými charakteristikami situácie nášho slovenského jazyka ako jazyka menšiny a v súvislosti s tým aj s dôsledkami kontaktu slovenčiny so srbčinou. Pri jednotlivých učebných témach sa berie zretel' aj na bežné kontaktové javy a vôbec na odklony od spisovnej slovenčiny a podnecuje sa tiež komunikačná zložka vyučovania slovenčiny. Ako novinka je do učebnic zaradená prekladatel'ská príloha s ciel'om, aby žiaci boli vedeni ku konfrontačnému pohladu na slovenčinu a srbčinu." (Myjavcová, 2009, s. 154). V rámci reforiem v školstve, tieto učebnice mali úplne novú didakticú koncepciu, obsah, náplň a praktické úlohy. Mnohé jazykové roviny preberala autorka zo Slovenska, ale sa prejavila ako vynikajúca odborníčka a znalkyňa vojvodinskej slovenčiny a slovensko-srbských jazykových vzt’ahov. Neustále zdôrazňovala na potrebu vzdelávat' sa $v$ materinskom jazyku, kultivovat' spisovnú slovenčinu, rozlíšit' slovnú zásobu dvoch kontaktových jazykov, zachovat' si slušný slovenský jazyk aj mimo hraníc Slovenska a na potrebu vytvárania priaznivých podmienok na používanie spisovnej slovenčiny vo všetkých sférach, a zároveň rozlišovanie nárečových a spisovných slov.

Za tento komplet učebníc autorka 21. septembra 2007 získala Cenu Stojana Novakovića ako za najlepšiu učebnicu národnostných menšín vydanú vo vydavatel'stve Zavod za udžbenike iz Beograda (Ústav pre učebnice v Belehrade).

Dôvod bol ten, že je to ucelená gramatika slovenského jazyka práve pre potreby vojvodinských Slovákov. Koncipovaná je tak, že podla potreby ju na hodinách slovenčiny môžu používat' stredoškoláci, ale zároveň je aj vhodná praktická pomôcka vo vyšších úrovniach vyučovania slovenčiny vo Vojvodine. Na rozdiel od predchádzajúcich učebníc, je tu množstvo praktických úloh (čo určite vplývalo aj na to, že učebnica namiesto v jednej knihe, vyšla v troch knihách). Tu sú praktické úlohy na zapamätanie si nového učiva, ale aj na upevnenie a úroveň úloh je prispôsobená ročníku a spracovaným jazykovým rovinám. Zaujímavé sú aj prekladové texty na konci každej učebnice, kde autorka podáva texty $\mathrm{v}$ srbčine a preklady do slovenčiny na znázornenie kvalitného prekladu. V učebniciach sú vo vel'kej miere zastúpené poučenia a pravopisné poučky. Tento posledný komplet učebníc predstavuje už vrcholný didaktický materiál, a môže byt' aj prehl'adná gramatika určená vojvodinským Slovákom na kultivovanie spisovnej slovečiny. 


\section{Záver}

Petrovské gymnázium bolo v minulosti dobrým opatrovníkom a zvelad'ovatel'om slovenského jazyka a potrebné je usilovne a vytrvalo pracovat' na tom, aby tak bolo aj v budúcnosti. Skutočnost', že si vojvodinskí Slováci boli schopní z vlastných síl utvorit' kvalitné učebnice zo slovenčiny, prispôsobené koncepčne súčasným potrebám a jazykovej situácii, v ktorej sú je pozoruhodné. Je to jedinečný prípad mimo hraníc Slovenska, ak hovoríme o slovenčine v enkláve. Dôležité je, napriek neprajným podmienkam a zníženiu počtu žiakov na stredných školách v tomto zotrvat' a uvedomit' si potrebu používania spisovnej slovenčiny a kultivovania jazyka. Petrovské gymnázium bolo a malo by aj nad’alej zostat' základným pilierom v zachovaní identity vojvodinských Slovákov. Vyučovanie a pestovanie slovenského spisovného jazyka (ako jedného zo základných činitel’ov zachovania identity) na gymnáziu v Petrovci bolo a malo by aj nad’aej byt' jedným z primárnych ciel’ov

\section{LITERATÚRA}

Dudok Daniel. „Úloha gymnázia v upevňovaní funkcie spisovného jazyka u nás“. Kmet’ Ján (red.). Petrovské gymnázium vo vývine slovenskej kultúry vo Vojvodine. Nový Sad: Obzor, 1970. s. 297-301.

Kačala Ján. „Učebnica slovenského jazyka z Juhoslávie“. Kultúra slova 23/5 (1989): 181-183.

Kmet’ Ján, Spevák Juraj, Hronec Vít’azoslav (red.). Samovzdelávajúci krúžok Sládkovič. Nový Sad: Obzor, 1976.

Kmet' Ján. Slovenská gramatika pre I. a II. triedu slovenských stredných škôl vo FL'RJ. Petrovec: Vydavatel'ský podnik Bratstvo-jednota, 1952.

Kmet' Ján. Slovenská gramatika pre III. a IV. triedu gymnázia alebo VII. a VIII. triedu osemročných škôl vo FL’RJ. Petrovec: Vydavatel'ský podnik Bratstvo-jednota, 1952.

Makišová Anna. „Mária Myjavcová - autorka učebníc“. Nový život 66/7-8 (2014): 47-50.

Mráz Andrej. Rozhovory o vojvodinských Slovákoch. Báčsky Petrovec: Kultúra 2004.

Myjavcová Mária. „Situácia slovenského jazyka v srbskej Vojvodine desat’ročia po Jozefovi Štolcovi“. Múcsková Gabriela (ed.). História, súčasný stav a perspektívy dialektologického bádania. Jazykovedné štúdie XXVI. Bratislava: VEDA vydavatel'stvo Slovenskej akadémie vied, 2009: 136-156.

Myjavcová Mária. Slovenský jazyk : pre 1. a 2. ročník spoločnej stredoškolskej výchovy a vzdelávania. Novi Sad: Pokrajinský ústav pre vydávanie učebníc, 1978

Myjavcová Mária. Slovenský jazyk : pre 1. a 2. ročník strednej školy. Nový Sad: Novi Sad: Pokrajinský ústav pre vydávanie učebníc, 1976.

Myjavcová Mária. Slovenský jazyk a kultúra vyjadrovania pre 1. ročník gymnázia. Beograd: Zavod za udžbenike i nastavna sredstva, 2005.

Myjavcová Mária. Slovenský jazyk a kultúra vyjadrovania pre 2. ročník gymnázia. Beograd: Zavod za udžbenike i nastavna sredstva, 2006.

Myjavcová Mária. Slovenský jazyk a kultúra vyjadrovania pre 3. a 4. ročník gymnázia. Beograd: Zavod za udžbenike i nastavna sredstva, 2009.

Myjavcová Mária. Slovenský jazyk a kultúra vyjadrovania pre I-IV. ročník strednej školy. Nový Sad: Pokrajinský ústav pre vydávanie učebníc, 1988.

Štolc Jozef. „Petrovské gymnázium a slovenský jazyk“. Kmet’ Ján (red.). Petrovské gymnázium vo vývine slovenskej kultúry vo Vojvodine. Nový Sad: Obzor, 1970: 293-295. 
Зузана Тирова

\section{СТОГОДИШЬА ПЕТРОВАЧКА ГИМНАЗИЈА У ПРОЦЕСУ ОЧУВАҢА КЬИЖЕВНОГ СЛОВАЧКОГ ЈЕЗИКА У ВОЈВОДИНИ И ГРАМАТИКЕ СЛОВАЧКОГ ЗА СРЕДњЕ ШКОЛЕ И ГИМНАЗИЈЕ}

\section{Резиме}

Настава словачког књижевног језика (као један од основних фактора очувања идентитета) у гимназији у Петровцу био је један од главних циљева од самог оснивања ове важне институције Словака у Војводини. Уџбеници су дуго времена проблем јер су најпре набављени из Словачке, а касније након захлађена односа између бивше Чехословачке и Југославије, наставници су морали бити сналажљиви како би студентима пружили добро знање и добре услове за учење. Граматику словачког језика за први и други разред академик Јан Кмећ је објавио 1952. године, а ону за трећи и четврти разред, две године касније 1954. године. Тек након четврт века, угледна лингвискиња Мариа Мијавец се појавила као стручњак и аутор уџбеника за средње школе. први уџбеник (1976. године), затим је 1988. издала нови, а тек у 21. веку излази комплетан сет за средње школе, који се састојао од три уџбеника $(2005,2006,2009)$, те покупио похвале и признања.

Кључне речи: Гимназија Јан Коллар, Јан Кмећ, Марија Мијавец, словачки, српски, граматик/уџбеник за гимназије и средње школе. 